\title{
The Role of the Adults' Educator in Teacher Training Programs
}

American Journal of Education and Learning

Vol. 5, No. 2, 152-158, 2020

e-ISSN:2518-6647

(T) Check for updates $\begin{gathered}\text { check for } \\ \text { updates }\end{gathered}$

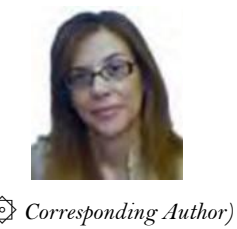

\author{
(iD) Eirini Tzovla ${ }^{10}$ \\ ID Katerina Kedraka ${ }^{2}$
}

${ }^{1,2}$ Laboratory of Teaching and Professional Development of Bioscientists, Department of Molecular Biology and Genetics, Democritus University of Thrace, Greece.

${ }^{2}$ Email:etzovla@mbg.duth.gr Tel:00306946558530

Email:kkedraka@mbg.duth.gr Tel:0302551030000

The adult educators must acquire formal and substantive qualifications and develop skills that contribute to achieving the best learning outcomes. This paper dealt with the role of the adults educator in teacher training programs. The role of the teacher training programs is to enhance an educational relationship, based on equity, between the teacher and the learner, with respect to the learners' needs and treatment as mature personalities with independent expertise. This research intended to investigate whether adult education methods are applied in teacher training programs and to describe the profile of the adult educator. The paper used the qualitative method. The major research results highlighted teachers believe that the adult educator plays a paramount role in their training and they insist that he must have good knowledge of adult education, experience as a trainer, and respect for his learners, empathy, and tolerance and he must also understand the special features of the adult learners.

Keywords: Adult learners, Teachers, Role of adult educator, Teacher training, Educational relationship, Respect.

DOI: $10.20448 / 804.5 .2 .152 .158$

Citation | Eirini Tzovla; Katerina Kedraka (2020). The Role of the Adults' Educator in Teacher Training Programs. American Journal of Education and Learning, 5(2): 152-158.

Copyright: This work is licensed under a Creative Commons Attribution 3.0 License

Funding: This study received no specific financialsupport.

Competing Interests: The authors declare that they have no competing interests.

History: Received: 7 August 2020/ Revised: 11 September 2020/ Accepted: 26 September 2020/ Published: 12 October 2020

Publisher: Online Science Publishing 


\section{Highlights of this paper}

- The profile of adult educator.

- The role of participatory climate in teachers' professional development.

- The importance of active participation and respect in adult education.

\section{INTRODUCTION}

The specific features and characteristics of adult learners demonstrate a different approach to learning and acquisition of knowledge (Rogers, 1992) than that adopted in students. These specific features indicate methods and techniques that activate the participation of learners, enhance the emotional relationship of all parts of the educational process, promote interaction, communication and shape the appropriate learning environment (Imel \& Tisdell, 1996). The category of adult learners also includes teachers, who, however, are a special professional group whose characteristics and special experiences presuppose another attitude of the adult educator and therefore another educational relationship, in which learners are treated as mature personalities with autonomous experience, knowledge and behavior. To ensure this educational relationship, an important role is played by the personality of the educator, who must secure an equal relationship among all the partners involved in learning, and have qualifications and skills that are in line with the requirements of his profession.

\section{QUALIFICATIONS AND SKILLS OF THE ADULT EDUCATOR}

The ongoing and increasing needs and changes that take place in all kinds of learning processes lead the adult educator to take on new roles, the multiplicity of which requires the acquisition of qualifications and the cultivation of a range of skills.In this regard, he must acquire formal and substantive qualifications and develop skills that contribute to achieving the best learning outcomes.

Jarvis (2004) argues that the adult educator must know the field of Adult Education, have skills to encourage the learners' freedom of thought and expression, accept their ideas, coordinate groups and complex activities effectively and understand learning conditions, motivations and characteristics of adults. Rogers and Freiberg (1994) and Rogers (1992) also argue that the adult educator should have the skills to create a positive and enjoyable atmosphere in the group of learners, to clarify in advance his intentions, to be a member of the group but at the same time outside of it, to offer learners "cognitive resources" (access to libraries, articles, books, educational materials, examples, etc.), to share thoughts and feelings with learners, to avoid imposing his views because of his "Authority", and to ensure the communication between learner and trainer. Furthermore, Corben and Thomson (2001) report that the adult educator should have the ability to be student-centered, strengthen the confidence of learners, have pedagogical training and knowledge of modern teaching techniques and believe in the value of education and training. The adult educator should be able to coordinate the learning process, to connect the educational environment with the workplace and the interests of the learners, to form an effective, flexible and structured learning environment, to apply reliable assessment procedures, to analyze issues innovatively and critically, to support learners effectively, to have up-to-date knowledge of his scientific field, to be original and innovative, to integrate into the educational process original educational techniques, to design together with the team the various sub-topics that compose a program, to encourage the critical attitude of the trainees in his own practices, knowledge and methods, to support and strengthen the communication and the contact with the external shareholders. According to Jarvis (2004) the multilevel role of the adult educator requires knowledge of the educational process, appropriate mentality and attitude, as well as educational and personal skills so that he can understand, communicate, coordinate, organize, mediate and support all phases of the learners' learning process. 


\section{TEACHERS AND TRAINING PROGRAMS}

Nowadays the professional development of teachers is required due to the constant changes in the environment of the learning society. This situation forms a new role for the teacher, who should constantly update his knowledge (Cochran-Smith \& Lytle, 2001; Lieberman, 1994) with the ultimate goal of changing students and at the same time making them independent. In addition, Dudzinski, Roszmann-Millican, and Sbank (2000) and Ganser (2000) argue that teacher training programs are effective when linked to the needs and daily activities of teachers and students, and Darling-Hammond (1988); Grace (1999) and Clement and Vandenberghe (2000) opine that the interaction among all parties involved in a training action makes it more effective.

Additionally, it should be noted that teachers, as a professional team, have experiences that make difficult to integrate the new knowledge into the pre-existing one. Rogers (1992) refers to this as "ab-learning" process, which requires a transformation, namely a critical consideration of pre-existing knowledge in order to teachers reconsider their views, be free from distorted assumptions and become "cooperative learners" (Mezirow, 1997). The role of the teacher trainer is catalytic in this process, as he forms those conditions that allow teachers to be more open, to process their knowledge and experience by interacting and communicating with the team and finally to facilitate the transformation process, issue of Adult Education (Mezirow, 1997). Also, according to Rogers (1992) the grade of participation of learners in a training program is influenced by the characteristics of the learner's personality, his culture, the phase in which his life is, his age and other personal parameters, features that are also found in teachers.

\section{RESEARCH DESIGN AND RESEARCH QUESTIONS}

The purpose of this study was to explore the role that the teacher educator plays in shaping a participatory climate in teacher education programs, which brought about the following research question: What are the characteristics of the trainer in shaping a participatory climate in a teacher training program?

The research question and the literature review led to the adoption of the qualitative method, as a method of approaching research, because it is appropriate in cases of problems, which must be investigated to ensure deep understanding (Creswell, 2008). The research involved six (6) Primary Education teachers, of different specialities, who had participated in different typologies of training activities and could contribute to the understanding of the central phenomenon of research.

Because the phenomenon in question was complex and complicated, the method of triangulation was chosen. The use of more than one data collection method (triangulation) enhanced the validity of the findings were the results derived from a co-examination of findings (Cohen, Manion, \& Morrison, 1994). The research instruments with which this research was carried out were interviews and the researcher's diary. An Interview Guide (interview protocol) was built based on the theoretical framework of the research and it included questions related to the research question. More specifically, the interview questions in which the research question was specialized were:

1. What role does the trainer play in shaping the participatory climate in the adult education program (one or more) in which you have participated?

2. What does the educator need to do to create a participatory climate in an adult education program?

3. In your opinion, what characteristics of the personality and experience of the educator depend on the configuration of the participatory climate in the adult education programs? Give a brief description of the "ideal" trainer.

4. From what you mentioned, which characteristic (qualification, element, etc) of the educator do you consider as the most important for the configuration of a participatory climate in the adult education programs? Why? 
The data were categorized into thematic categories to give meaning to parts of the interviews and the observation diary and to convert the contents of the interviews and the diary into summary findings, which were then commented on and interpreted in qualitative terms. A qualitative content analysis was used as a method of analysis (Creswell, 2008).

\section{RESULTS AND DISCUSSION}

The results of the research revealed the catalytic role that the teacher trainer plays and the importance of his skills in shaping a participatory climate.

Initially, some participants in the research reported the role of coordinator, facilitator and animator to the trainer. However, because the above roles were not highlighted by all participants, they were not mentioned extensively and did not develop in-depth, it was not possible to draw sufficient conclusions about these roles.

Respondent A: "The trainer is the captain. He has the main role; he will be able to take the team one step further than the expectations of the team itself."

Respondent B: "It plays a key role; it is the one who coordinates, the one who guides us."

Then, the value of the active involvement of the trainees and the use of active teaching techniques by the trainer was pointed out by all participants.

Respondent C: "... To exchange views on issues that concern us and we face in our classroom... in this way, the training and the seminar become more functional and experiential because through these experiential actions we learn better. When e.g. we are the teachers of the first grade of the primary school and we do working in groups, role plays or exercises that concern our class, we will be given more time to share opinions and concerns on issues that concern us."

These observations are reinforced by the views of great theorists in the field of Adult Education such as Freire, Kolb, Mezirow, Rhace, Noyé-Piveteau, Courau who declare that the adult learns when he acts and is involved. Therefore, the importance of the active participation of the trainees in the adult education programs is of great importance.

The participants also mentioned the adult educator must take into account the experiences of the trainees, respect and accept the different views.

Respondent B: "To take into account the questions and experiences of teachers and not to go beyond them ... The experiences of colleagues in the same speciality also helped a lot."

Respondent D: "To ensure that there is a climate of courtesy and acceptance... because each trainee has his own character, his own way of expression and many times can escape the climate."

These answers were also in line with the theoretical framework of Adult Education. As argued by Fraser, Freire, Macedo, McKinnon, and Stokes (1997); Mezirow (1981) and Jarvis, Holford, and Griffin (2003) the integration of pre-existing experiences in the learning process and the trigger for thinking on them enhance the personal development, professional development and self-knowledge of the trainees but also the collaborative spirit, which, according to Freire (2018) are the "background" for all learning principles to work. Similarly, Rogers. and Freiberg (1994) and Rogers (1992) believe that the educator should share their thoughts and feelings with the learners, integrate their experiences into the learning process and enhance communication among the learner and the trainer.

In addition, all respondents stated that the most important qualifications of the trainer's personality are the knowledge of his subject and the knowledge of the field of Adult Education.

Respondent E: "To know his subject well and to show that he is safe about it." 
Respondent D: "...But to know how to work with adults and to know how to manage them, because adults also have their own problems, the personal ones, which they can carry during the training."

Respondent B: "Must definitely have experience in adult education."

In this term, the adult educator must have up-to-date knowledge of his scientific field. Corben and Thomson (2001) indicate the adult educator should have pedagogical training and knowledge of modern teaching techniques, and Jarvis (2004) argues that the adult educator must know the field of Adult Education. Similarly, some of the participants in the research referred as characteristic of the adult educator the experience of the trainer himself as a trainee.

Respectively, according to Gow and Kember (1993) and Jarvis (2004) the adult educator must have been properly trained himself in matters relating to adult education in order to understand the reasons why group education is used in adult education because otherwise it is faced with a number of problems in the field of communication. In addition, the other characteristics of the adult educator, which were also mentioned by the participants in the research, include respect for the trainees, active listening, empathy and parity in the group without considering themselves an authority, findings that are reinforced in the literature by many of its researchers.

Respondent F: "Mainly because of the feeling he gives to others that he treats them with respect. He does not let them feel any threat from him; which he knows wisely and which they must adopt."

Knowles (1989) also concludes that the educator enhances the self-esteem of adults, treats them with respect, boost freedom of expression and creates a friendly atmosphere, and Freire (2018) speaks of "mutual respect". Similarly, the trainer in Rogers (2007) is possessed by empathy, interest in his learners and creates in his team an atmosphere of mutual trust and intimacy. Heimlich and Norland (1994); Cranton and Carusetta (2004) and Brookfield (1986) point out that the trainer must renounce the characteristic of authority.

Respondent E: "To win over his audience, his trainees and lead them to new knowledge; convincing them that he is have and to new knowledge themselves. "

Finally, the research showed that the most important qualifications of the adult educator that promote participation are the use of active teaching techniques, the active participation of the trainees, the provision of sufficient time to the trainees, the respect of the different points of view, the adoption of dialogue, the understanding of particularities of adults, characteristics which exist in the broader field of Adult Education. According to Rogers (1992); Noyé and Piveteau (1999) and Courau (2000) the adoption of active teaching techniques makes trainees participants in the learning process and responsible for their development and affects the social goals of education. Enhancement of active participation is a key principle in the field of Adult Education and contributes to the formation of a climate of trust, cooperation and exchange and respect for the different point of view and as argued by Courau (2000) promotes the formation of a friendly climate.

Respondent F: "If the trainer does not exude and does not show respect, then he will not be respected by the team nor will he respect the team. So no relationship of interaction, mutual aid, teamwork will develop because team means team spirit. If there is no team spirit, there will be no team atmosphere, so learning is not encouraged."

Referring to dialogue, which is a cornerstone in creating a participatory climate, Fraser et al. (1997) emphasizes that the adult educator is not considered the holder of the truth, who transmits knowledge vertically to the learners (banking perception of education) but the one who triggers discussion, adopts dialogue and promotes cooperation. Similarly, Mezirow (1997) argues that the adult educator should take a stand in favor of the change, to promote rational dialogue and participation, to avoid dogmatism, and to create "protective learning environments" in which the necessary "conditions of social democracy" are strengthened. 


\section{CONCLUSIONS}

Concluding the presentation of the research, the following conclusions can be drawn about the role of the adult educator as a teacher educator.

- The instructor plays a catalytic role in creating a participatory climate and elements of coordinator, facilitator and animator of the learning process are attributed to him.

- The adult educator should actively involve the trainees, apply active teaching techniques, take into account the experiences of the trainees and respect and accept the other point of view to contribute to the formation of a participatory climate.

- The characteristics of the adult educator on which the creation of a participatory climate depends include: the knowledge of his subject, the knowledge of the field of Adult Education, the experience of the trainer himself as a trainee, the respect of the trainees, the adoption of techniques of active listening and empathy, the enhancement of an equal relationship with the trainees.

- The most important characteristic of the adult educator for the formation of a participatory climate is the use of active educational techniques, the promotion of the active participation of the trainees, the provision of sufficient time to them so as to promote dialogue and understand the specific future of adult learners.

\section{IMPLICATIONS AND LIMITATIONS}

In this research, the coordinating, facilitating and animating role of the adult educator was not sufficiently referred, which allows the future researcher to continue the research by focusing on the investigation of the above roles, as well as the additional formal and substantive qualifications and skills that would enable the adult educator to respond as successfully as possible to their diverse role.

It should also be noted that, like any research, this study has its limitations.First of all, this was a small-scale study and the qualitative analysis was based on the views of the surveyed teachers in a specific area, which does not allow the generalization of the results to all teachers. It was concluded, therefore, that in no case is the universal character of the findings supported, but we intend to highlight essential aspects of the educational process and of the educational work that take place in the teacher training programs.

\section{REFERENCES}

Brookfield, S. (1986). Understanding and facilitating adult learning: A comprehensive analysis of principles and effective practices: McGraw-Hill Education (UK).

Clement, M., \& Vandenberghe, R. (2000). Teachers' professional development: A solitary or collegial (ad) venture? Teaching and Teacher Education, 16(1), 81-101. Available at: https://doi.org/10.1016/s0742-051x(99)00051-7.

Cochran-Smith, M., \& Lytle, S. L. (2001). Beyond certainty: Taking an inquiry stance on practice. In Lieberman, A.; Miller, L. (Eds), Teachers caught in the action: professional development that matters. New York: Teachers College Press.

Cohen, L., Manion, L., \& Morrison, K. (1994). Educational research methodology. Athens: Metaixmio.

Corben, H., \& Thomson, K. (2001). What makes a great teacher? Attributes of excellence in VET. Paper presented at the In TAFE Educational Services Research Conference, Sydney, Australia. Retrieved November (2015).

Courau, S. (2000). The basic'tools of instructor of adults. Athens: Metaihmio.

Cranton, P., \& Carusetta, E. (2004). Perspectives on authenticity in teaching. Adult Education Quarterly, 55(1), 5-22.

Creswell, J. W. (2008). Planning, conducting and evaluating quantitative ad quantitative research. Educational Research. Upper Saddle River, NJ: Pearson Education Inc. 
Darling-Hammond, L. (1988). The futures of teaching. Educational Leadership, 46(3), 4-10.

Dudzinski, M., Roszmann-Millican, M., \& Sbank, K. (2000). Continuing professional development for special educators: Reforms and implications for unj" tversity programs. Teacher Education and Special Education, 23(2), 109-124.

Fraser, J., Freire, P., Macedo, D., McKinnon, T., \& Stokes, W. (1997). Mentoring the mentor: A critical dialogue with Paulo Freire: Peter Lang. $\quad$ Retrieved from: http://bvbr.bibbvb.de:8991/F?func $=$ service $\&$ doc_library $=$ BVB01\&local_base $=$ BVBO $1 \&$ doc_number $=007576433 \&$ line_number $=0001$ \&func_code=DB_RECORDS\&service_type=MEDIA.

Freire, P. (2018). Pedagogy of the oppressed. USA: Bloomsbury Publishing.

Ganser, T. (2000). An ambitious vision of professional development for teachers. NASSP Bulletin, 84(618), 6-12.

Gow, L., \& Kember, D. (1993). Conceptions of teaching and their relationship to student learning. British Journal of Educational Psychology, 63(1), 20-23. Available at: https://doi.org/10.1111/j.2044-8279.1993.tbo1039.x.

Grace, D. (1999). Paradigm lost (and regained). Independent School, 59(1), 54-57.

Heimlich, J. E., \& Norland, E. (1994). Developing teaching style in adult education. The Jossey-Bass higher and adult education serie. San Francisco, CA Jossey-Bass, Publishers.

Imel, S., \& Tisdell, E. J. (1996). The relationship between theories about groups and adult learning groups. New Directions for Adult and Continuing Education, 71, 15-24. Available at: https://doi.org/10.1002/ace.36719967104.

Jarvis, P. (2004). Adult education and lifelong learning: Theory and practice. London: Routledge.

Jarvis, P., Holford, J., \& Griffin, C. (2003). The theory \& practice of learning. London and New York: Routledge Falmer.

Knowles, M. S. (1989). The making of an adult educator: An autobiographical journey: Jossey-Bass Inc Pub.

Lieberman, A. (1994). Teacher development: commitment and challenge. In P.P. Grimmet \& J. Neufeld (Eds.), Teacher development and the struggle for authenticity (pp. 15-30). New York: Teachers College Press.

Mezirow, J. (1981). A critical theory of adult learning and education. Adult Education, 32(1), 3-24.

Mezirow, J. (1997). Transformation theory out of context. Adult Education Quarterly, 48(1), 60-62. Available at: https://doi.org/10.1177/074171369704800105.

Noyé, D., \& Piveteau, J. (1999). A reference manual for instructors. Athens: Metehmio.

Rogers, A. (1992). Adults learning for development. London: Cassell.

Rogers, C. R., \& Freiberg, H. J. (1994). Freedom to learn (3rd ed.). Columbus, OH: Merrill.

Rogers, A. (2007). The necessary and sufficient conditions of therapeutic personality change. Psychotherapy: Theory, Research, Practice, Training, 44(3), 240-248. Available at: https://doi.org/10.1037/0033-3204.44.3.240.

Online Science Publishing is not responsible or answerable for any loss, damage or liability, etc. caused in relation to/arising out of the use of the content. Any queries should be directed to the corresponding author of the article. 